\title{
Absence of toxic effects by food yeast on the rat
}

\author{
By A. E. BENDER AND B. H. DOELL \\ 2 Avalon Road, Ealing, London, W.13 \\ (Received 23 September I959-Revised 4 February 1960)
}

There is little doubt as to the potential value of yeast in the human diet, particularly as a source of protein and B vitamins, but its use is rarely considered except in times of emergency. Two factors militate against the use of yeast: first, it appears that the consumption of amounts greater than $15 \mathrm{~g} /$ day can cause digestive disturbances, at least in some individuals; secondly, the material has no structure of its own and needs to be incorporated into other foods.

Our investigation was made in an attempt to resolve the conflicting reports about the toxicity of yeast to mammals. A memorandum of the Medical Research Council: Accessory Food Factors Committee (1945) concludes that some individuals cannot tolerate yeast in quantities greater than $10-15 \mathrm{~g} /$ day. There does not appear to be any explanation of this intolerance. One suggestion (unpublished) was that the yeast used for the work described in the Memorandum was contaminated with an antifoaming agent (sulphonated fish oil) used in its manufacture.

In the I4 years since publication of the Memorandum improvements in methods of manufacture and the use of other anti-foaming agents yield a product that might differ from the earlier material. We have made the attempt to find out whether $(a)$ food yeast produced under controlled conditions shows ill-effects in the rat, and $(b)$ any differences could be shown between Torulopsis utilis and two other strains of food yeast. Our work was not so much concerned to confirm the beneficial properties of yeast as to determine whether any harmful effects on the rat could be detected.

\section{EXPERIMENTAL}

Yeasts

Varieties. Three varieties of yeast were used, Torulopsis utilis, Zygosaccharomyces lactis and Candida arborea. The T. utilis was derived from the strain originally used in the D.S.I.R. Chemical Research Laboratory, Teddington; the $C$. arborea from the strain used for food-yeast production in Germany during $1939-45$; the $Z$. lactis from the Centraalbureau voor Schimmelcultures at Delft.

Preparation. The yeasts were produced in a pilot plant by growth on a refinery cane-molasses medium enriched with a suitable source of nitrogen. The inoculum was prepared in a small seed fermenter and was transferred at the end of the logarithmic growth phase to a larger fermenter (100 l. working capacity) in which further growth was regulated by incremental feeding. A small quantity of a silicone antifoaming agent was added to the medium in the seed fermenter only, none being used 
in the main fermenter, where reliance was placed on a mechanical foam-breaker. The amount of anti-foaming agent in the final product was consequently negligible. Operations were conducted throughout under strictly aseptic conditions, and bacteriological examination of the fermenter contents at intervals showed that the growth consisted of a pure culture of the specific yeast. Air entered the fermenter through a single orifice, at the rate of $\mathrm{I} 1 . / 1$ liquid $/ \mathrm{min}$. An eight-vaned paddle, rotating at I000 rev/min, was located centrally above the air intake. At the end of the growth period the culture was centrifuged, and the residue was washed three times with water by further centrifugation. The cream of washed cells was dried on a roller drier.

Table I. Mean composition on a dry-weight basis of the yeast preparations used

Constituent*

Crude protein $(\mathrm{N} \times 6 \cdot 25)(\%)$

Purine $(\%)$

Ash (\%)

Fat $(\%)$

Total N (\%)

Thiamine $(\mu \mathrm{g} / \mathrm{g})$

Nicotinic acid $(\mu \mathrm{g} / \mathrm{g})$

Riboflavin $(\mu \mathrm{g} / \mathrm{g})$

Folic acid $(\mu \mathrm{g} / \mathrm{g})$

Biotin $(\mu \mathrm{g} / \mathrm{g})$

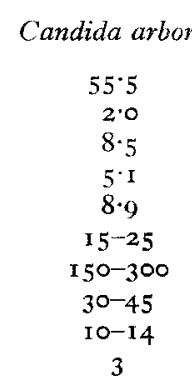

3

Zygosaccharomyces
lactis
$58 \cdot 3$
$2 \cdot 3$
$9 \cdot 2$
$6 \cdot 3$
$9 \cdot 3$
$25-30$
$125-180$
$50-65$
$6-7$
3

* The remainder not accounted for is usually considered to be carbohydrate of undetermined composition.

Chemical properties. Several preparations of each yeast were used during the experiment; their mean compositions are shown in Table I.

Quantity in diet. Quantities of yeast as small as $\mathrm{I}$ g/day could make a reasonable contribution even to the British diet. This amount would add approximately $7 \%$ to the protein, $80 \%$ to the thiamine, $30 \%$ to the riboflavin and $30 \%$ to the nicotinic acid of the average diet. To allow for the differences between intakes of food by rat and man, the level of yeast in the experimental diet can be calculated on either food intake or relative body-weight. For example, to obtain the equivalent of $10 \mathrm{~g}$ yeast/day for a $70 \mathrm{~kg}$ man the rat's diet would need to contain $0.1-0.3 \%$ yeast on a body-weight comparison or about $1 \cdot 5 \%$ on a food-intake comparison.

The lowest level used in our experiment was $3 \%$, as the literature reports digestive disorders after consumption of amounts greater than $\times 5^{-3}-\mathrm{g}$ daily. The higher levels of 6,9 and $12 \%$ were given in the hope of emphasizing any minor effects. The $21 \%$ level was included as possibly representing gross maltreatment.

\section{Diet}

The basic diet was that of Thomson ( $193^{6}$ ) containing $23.5 \%$ protein, $3 \%$ fat and $5 \%$ fibre, together with $40 \mathrm{ml} \mathrm{milk} /$ week and $0.1 \mathrm{ml}$ cod-liver oil four times a week and $0.1 \mathrm{ml}$ wheat-germ oil once a week. To it the yeasts were added in the proportions stated. 


\section{Animals}

One hundred and forty-four albino rats (purchased from the Mousery, Rayleigh, Essex) were used, four males and four females on each diet, together with twenty-four control animals. The animals were fed ad lib.

\section{Plan of experiment}

Gain in weight and efficiency of food conversion. A simple experiment was done. The animals were weighed weekly and their food consumption was measured.

Examination of the blood, tissues and urine. After 4-6 months' feeding two rats, one male and one female, on each diet were examined. They were killed with diethyl ether and weighed, and carcass length (nose to tail-root) and overall body length (nose to tail-tip) were measured.

The thorax was opened, and a sample of blood was taken from the heart for $(a)$ haemoglobin estimation $\left(20 \mathrm{~mm}^{3}\right.$ blood in $4.0 \mathrm{ml} 0.04 \%(\mathrm{v} / \mathrm{v})$ conc. ammonia solution), (b) red-cell count $\left(20 \mathrm{~mm}^{3}\right.$ blood in $4.0 \mathrm{ml}$ Hayem's solution), and $(c)$ white-cell count (sample diluted $\mathrm{I}: 20$ in a white-cell diluting pipette with $3 \%(\mathrm{v} / \mathrm{v})$ acetic acid). Red and white cells were counted in a Neubauer counting chamber. A differential cell count was also made on a dried film of blood.

The haemoglobin was estimated by measurement of the optical density (o.D.) of the diluted blood in a Unicam SP 600 Spectrophotometer at $540 \mathrm{~m} \mu$; o.D. $\times 22 \cdot 2=$ haemoglobin in $\mathrm{g} / 100 \mathrm{ml}$ blood. This factor was checked, by means of a sample of blood distributed under the Haemoglobin Standards Scheme, by C. Davis Keeler Ltd, 47 Wigmore Street, London W. I.

The spleen, thymus, liver, both kidneys and both adrenals were removed from the carcass, trimmed of fat and connective tissue, roughly dried on filter-paper and weighed immediately. A sample of the liver was dried at $105^{\circ}$ overnight to determine dry weight, and the dried sample was extracted for $5 \mathrm{~h}$ in a Soxhlet extractor with diethyl ether to determine fat.

A sample of urine was collected in a syringe through the bladder wall and examined immediately under the microscope.

The liver and adrenal glands were examined in frozen section after staining with Sudan IV. Samples of liver, adrenals, spleen, thymus and kidneys were processed in the usual manner in paraffin wax and stained with haematoxylin and eosin.

Fertility. The seventy-two rats remaining after half of the animals had been killed for examination were mated, and the number and weight of litters were recorded.

\section{RESULTS}

\section{Gain in weight and efficiency of food conversion}

The weights of the animals after 4,8 and I 3 weeks are listed in Table 2. Statistical examination showed no significant difference between the control groups for each type of yeast and the groups on any level of yeast after 13 weeks.

The food consumption and efficiency of food conversion are shown in Table 3 . No consistent differences were observed. 


\section{Examination of blood, tissues and urine}

Organ weights and blood values. The mean weights of spleen, thymus, adrenals, kidneys and livers of controls and treated animals are shown in Table 4. For brevity the values for the animals given 3 and $6 \%$ yeast were combined and the values for those given $9 \%$ omitted. Carcass and overall body lengths, weight, fat and water content of liver, red-cell counts and haemoglobin are also shown. White-cell counts showed extremely wide variations within groups.

Table 2. Mean body-weights of groups of four rats given different yeasts (Candida arborea, Zygosaccharomyces lactis and Torulopsis utilis) at various levels in the diet

Level of yeast in $\operatorname{diet}(\%)$

\begin{tabular}{|c|c|c|c|c|c|c|c|c|c|c|c|c|}
\hline \multirow[b]{2}{*}{ Yeast } & \multicolumn{2}{|c|}{0} & \multicolumn{2}{|c|}{3} & \multicolumn{2}{|c|}{6} & \multicolumn{2}{|c|}{9} & \multicolumn{2}{|c|}{12} & \multicolumn{2}{|c|}{21} \\
\hline & $\delta$ & \& & $\hat{0}$ & o & $\delta$ & 웅 & 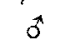 & 우 & $\sigma$ & 우 & 0 & 운 \\
\hline \multicolumn{13}{|c|}{ Initially } \\
\hline $\begin{array}{l}\text { C. arborea } \\
Z \text {. lactis } \\
T . \text { utilis }\end{array}$ & $\begin{array}{l}54 \\
66 \\
68\end{array}$ & $\begin{array}{l}56 \\
59 \\
65\end{array}$ & $\begin{array}{l}54 \\
66 \\
68\end{array}$ & $\begin{array}{l}56 \\
59 \\
65\end{array}$ & $\begin{array}{l}54 \\
66 \\
68\end{array}$ & $\begin{array}{l}56 \\
59 \\
65\end{array}$ & $\begin{array}{l}55 \\
66 \\
68\end{array}$ & $\begin{array}{l}56 \\
59 \\
65\end{array}$ & $\begin{array}{l}55 \\
66 \\
68\end{array}$ & $\begin{array}{l}56 \\
59 \\
65\end{array}$ & $\begin{array}{l}54 \\
66 \\
68\end{array}$ & $\begin{array}{l}56 \\
59 \\
65\end{array}$ \\
\hline \multicolumn{13}{|c|}{ At 4 weeks } \\
\hline C. arborea & I5O & 127 & 142 & 131 & I 54 & 132 & 154 & 123 & 134 & 124 & 133 & I 13 \\
\hline Z. lactis & 171 & 118 & 167 & 124 & 162 & 120 & 165 & 129 & 165 & 132 & 166 & 144 \\
\hline$T$, utilis & I 53 & 130 & 162 & 129 & I 57 & 124 & 160 & 128 & I 54 & 126 & I $5 \mathrm{I}$ & 127 \\
\hline \multicolumn{13}{|c|}{ At 8 weeks } \\
\hline C. arborea & 213 & 163 & 200 & 174 & 214 & 170 & 213 & I 54 & 197 & ${ }^{1} 5^{I}$ & I 87 & 149 \\
\hline Z. lactis & 248 & 152 & $23^{8}$ & 158 & 229 & I 51 & 239 & 162 & 216 & I66 & 233 & 166 \\
\hline T. utilis & 223 & 162 & 220 & 158 & 209 & 156 & 221 & $16 r$ & 213 & I 58 & 206 & r 52 \\
\hline \multicolumn{13}{|c|}{ At 13 weeks } \\
\hline C. arborea & 253 & 179 & 222 & 190 & $25 \mathrm{I}$ & 186 & 252 & I66 & 223 & 175 & 227 & I67 \\
\hline Z. lactis & 289 & 162 & 275 & 170 & 255 & 166 & 277 & $\mathbf{1} 7^{8}$ & $25^{\circ}$ & 182 & 263 & 185 \\
\hline$T$. utilis & 255 & 175 & $26 I$ & 173 & 237 & I 66 & 250 & I 80 & 249 & I 74 & 249 & 172 \\
\hline
\end{tabular}

None of the values differed significantly from those for the controls, with the possible exception of the liver weights of the males given 3 and $6 \%$ yeast in the diet (values combined) and $2 \mathrm{I} \%$. These were significantly different at the $5 \%$ level only.

The values were also calculated in relation to body-weight and to body length. They showed no significant difference between the groups, and the figures are omitted.

Histological examination of tissues. In all, two male and two female rats on each of the three yeasts at each of the five levels of feeding were examined. The tissues examined (see p. 307) showed no obvious abnormalities.

Urine. The samples of urine examined showed no difference between control and treated rats. Samples from several animals of all groups contained spermatozoa and occasional nematode eggs (a few animals were heavily infested); few samples contained red blood cells.

Fertility. The fertilities are shown in Table 5. Female rats on each diet were mated with males from the same group and remated a second time as soon as the first litter 
was weaned. As no difference was apparent between the different yeasts, results for all three have been combined in the table. They show a high degree of fertility with no apparent harm from the yeast.

Mortality. Of all the rats five died from unknown causes or were moribund and

Table 3. Consumption and efficiency of conversion of food by the rats given different yeasts at various levels in the diet

(Mean values for groups of four animals)

Period

\begin{tabular}{|c|c|c|c|c|c|c|c|c|c|}
\hline \multirow[b]{2}{*}{$\begin{array}{l}\text { Level of } \\
\text { yeast in } \\
\text { diet } \\
(\%)\end{array}$} & \multicolumn{3}{|c|}{ o-4 weeks } & \multicolumn{3}{|c|}{ 4-8 weeks } & \multicolumn{3}{|c|}{$8-1_{3}$ weeks } \\
\hline & $\begin{array}{l}\text { Food } \\
\text { eaten } \\
(\mathrm{g})\end{array}$ & $\begin{array}{l}\text { Weight } \\
\text { gain } \\
\text { (g) }\end{array}$ & $\begin{array}{c}\text { Food } \\
\text { eaten }(\mathrm{g}) / \\
\text { g weight } \\
\text { gain }\end{array}$ & $\begin{array}{l}\text { Food } \\
\text { eaten } \\
(\mathrm{g})\end{array}$ & $\begin{array}{l}\text { Weight } \\
\text { gain } \\
\text { (g) }\end{array}$ & $\begin{array}{c}\text { Food } \\
\text { eaten }(\mathrm{g}) / \\
\mathrm{g} \text { weight } \\
\text { gain }\end{array}$ & $\begin{array}{l}\text { Food } \\
\text { eaten } \\
\text { (g) }\end{array}$ & $\begin{array}{l}\text { Weight } \\
\text { gain } \\
\text { (g) }\end{array}$ & $\begin{array}{c}\text { Food } \\
\text { eaten }(\mathrm{g}) / \\
\text { g weight } \\
\text { gain }\end{array}$ \\
\hline
\end{tabular}

Candida arborea

\begin{tabular}{|c|c|c|}
\hline$\delta$ & 0 & 348 \\
\hline q & 0 & 306 \\
\hline 8 & 3 & 362 \\
\hline 9 & 3 & 336 \\
\hline$\delta$ & 6 & 360 \\
\hline 우 & 6 & 356 \\
\hline 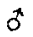 & 9 & 359 \\
\hline 9 & 9 & 347 \\
\hline 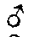 & 12 & 328 \\
\hline 우 & 12 & 325 \\
\hline$\delta$ & 21 & 346 \\
\hline 9 & 21 & 296 \\
\hline
\end{tabular}

$\begin{array}{rr}96 & 3 \\ 72 & 4 \\ 87 & 4 \\ 76 & 4 \\ 100 & 3 \\ 76 & 4 \\ 70 & \\ 100 & 3 \\ 67 & 5 \\ 80 & 4 \\ 68 & 4 \\ 78 & 4 \\ 58 & 5 \\ \end{array}$

$\begin{array}{rrr} & \text { Candia arborea } \\ 3 \cdot 6 & 504 & 6 \\ 4 \cdot 3 & 375 & 35 \\ 4 \cdot 2 & 450 & 5 \\ 4 \cdot 4 & 441 & 43 \\ 3 \cdot 6 & 532 & 6 \\ 4 \cdot 7 & 454 & 3 \\ 3 \cdot 6 & 475 & 5 \\ 5 \cdot 2 & 400 & 3 \\ 4 \cdot 1 & 483 & 6 \\ 4 \cdot 8 & 405 & 28 \\ 4 \cdot 4 & 448 & 5 \\ 5 \cdot 1 & 391 & 3\end{array}$

$\begin{array}{rr}63 & 8 \cdot 0 \\ 35 & 10.7 \\ 58 & 7 \cdot 8 \\ 43 & 10.3 \\ 60 & 8 \cdot 9 \\ 38 & 11 \cdot 9 \\ 59 & 8 \cdot 1 \\ 31 & 12.9 \\ 63 & 7 \cdot 7 \\ 28 & 14.5 \\ 55 & 8 \cdot 1 \\ 36 & 10.9\end{array}$

618
455
581
503
623
491
592
337
599
459
590
434

$\begin{array}{ll}40 & 15 \cdot 4 \\ 16 & 28 \cdot 4 \\ 22 * & 26 \cdot 4 \\ 17 & 29 \cdot 6 \\ 37 & 16 \cdot 8 \\ 16 & 30 \cdot 6 \\ 39 & 15 \cdot 2 \\ 12 & 28 \cdot 1 \\ 26 & 23 \cdot 0 \\ 24 & 19 \cdot 1 \\ 39 & 15 \cdot 1 \\ 18 & 24 \cdot 1\end{array}$

\section{Zygosaccharomyces lactis}

$\begin{array}{lll}\delta & 0 & 347 \\ 9 & 0 & 300 \\ \delta & 3 & 398 \\ 0 & 3 & 328 \\ \delta & 6 & 389 \\ 0 & 6 & 310 \\ \delta & 9 & 425 \\ \circ & 9 & 330 \\ \delta & 12 & 388 \\ 0 & 12 & 338 \\ \delta & 21 & 383 \\ \varnothing & 21 & 302\end{array}$

$\begin{array}{rr}105 & 3 \\ 59 & 5 \\ 101 & 3 \\ 66 & 5 \\ 96 & 4 \\ 62 & 5 \\ 99 & 4 \\ 70 & 4 \\ 99 & 3 \\ 73 & 4 \\ 100 & 3 \\ 71 & 4 \\ 71\end{array}$

$3 \cdot 3$
$5 \cdot 1$
$3 \cdot 9$
$5 \cdot 0$
$4 \cdot 1$
$5 \cdot 0$
$4 \cdot 3$
$4 \cdot 7$
$3 \cdot 9$
$4 \cdot 6$
$3 \cdot 8$
$4 \cdot 3$

574
375
537
436
554
396
497
357
471
417
488
391

$\begin{array}{rr}52 & 11 \cdot 0 \\ 35 & 10 \cdot 7 \\ 71 & 7 \cdot 6 \\ 34 & 12 \cdot 8 \\ 67 & 8 \cdot 3 \\ 30 & 13 \cdot 2 \\ 75 & 6 \cdot 6 \\ 34 & 10 \cdot 5 \\ 52 & 9 \cdot 1 \\ 34 & 12 \cdot 3 \\ 67 & 7 \cdot 3 \\ 37 & 10.6\end{array}$

\section{0}

424

605

444

602

444

613

474

586

464

670

\section{Torulopsis utilis}

\begin{tabular}{|c|c|c|}
\hline $\bar{\delta}$ & 0 & $3^{8} 4$ \\
\hline & 0 & 326 \\
\hline & 3 & 377 \\
\hline & 3 & $3^{6} \sigma_{3}$ \\
\hline & 6 & 402 \\
\hline q & 6 & 367 \\
\hline$\hat{0}$ & 9 & 420 \\
\hline & 9 & 348 \\
\hline$\hat{0}$ & 12 & 377 \\
\hline q & 12 & 323 \\
\hline$\sigma^{*}$ & 21 & $3^{888}$ \\
\hline & $2 x$ & 314 \\
\hline
\end{tabular}

85
64
94
64
89
59
92
63
86
61
83
62

$\begin{array}{lll}4 \cdot 5 & 538 & 7 \\ 5 \cdot 1 & 453 & 3 \\ 4 \cdot 0 & & 5 \\ 5 \cdot 7 & 402 & 3 \\ 4 \cdot 3 & 512 & 5 \\ 6 \cdot 2 & 414 & 3 \\ 4 \cdot 6 & 555 & 6 \\ 5 \cdot 5 & 436 & 33 \\ 4 \cdot 4 & 568 & 59 \\ 5 \cdot 3 & 406 & 3 \\ 4 \cdot 7 & 558 & 55 \\ 5 \cdot 1 & 406 & 25\end{array}$

$\begin{array}{rr}70 & 7 \cdot 7 \\ 33 & 13 \cdot 7 \\ 58 & \\ 30 & 13 \cdot 4 \\ 52 & 9 \cdot 8 \\ 32 & 12 \cdot 9 \\ 61 & 9 \cdot 1 \\ 33 & 13 \cdot 2 \\ 59 & 9 \cdot 6 \\ 32 & 12 \cdot 7 \\ 55 & 10.1 \\ 25 & 16.2\end{array}$

647

483

657

445

580

440

628

479

633

445

628

467

$\begin{array}{ll}31 & 20 \cdot 6 \\ 10 & 42 \cdot 4 \\ 37 & 16 \cdot 4 \\ 12 & 37 \cdot 0 \\ 27 & 22 \cdot 3 \\ 16 & 27 \cdot 8 \\ 38 & 16 \cdot 1 \\ 15 & 31 \cdot 6 \\ 34 & 17 \cdot 2 \\ 17 & 27 \cdot 3 \\ 30 & 22 \cdot 3 \\ 19 & 25 \cdot 1\end{array}$

* One animal was losing weight. 


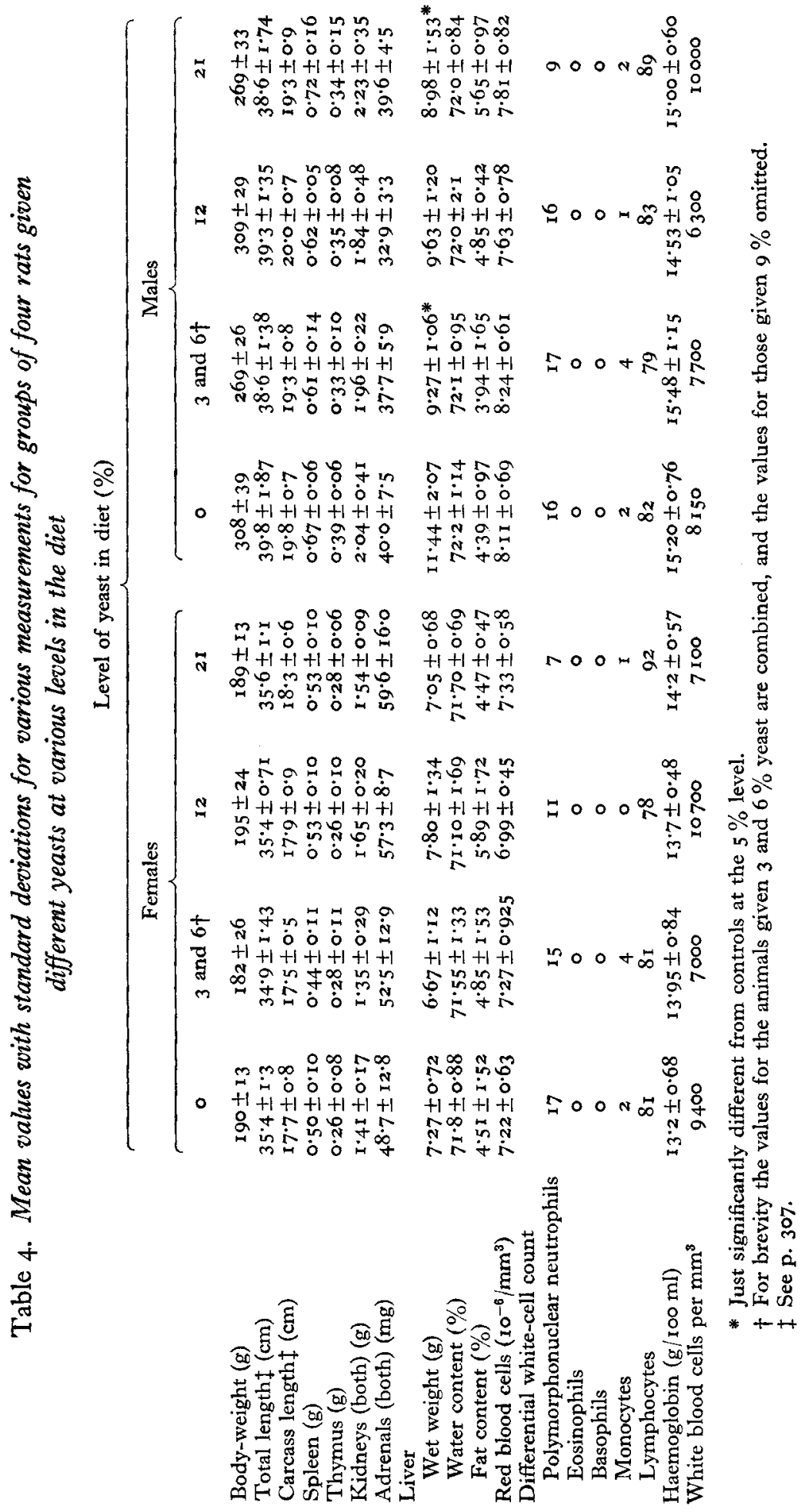


therefore killed: one on the $3 \% Z$. lactis diet, one on $3 \%$, one on $12 \%$ and one on 2r \% C. arborea, and one on $21 \% T$. utilis. None of the controls died, but so low a mortality during a 6-month experiment with no pattern indicating particular cause did not incriminate the yeast diet.

Table 5. Fertility of rats given different yeasts* at various levels in the diet

$\begin{array}{ccccccccc}\begin{array}{c}\text { Level of } \\ \text { yeast in } \\ \text { diet } \\ (\%)\end{array} & \begin{array}{c}\text { No. } \\ \text { mated }\end{array} & \begin{array}{c}\text { No. giving } \\ \text { birth }\end{array} & \begin{array}{c}\text { No. } \\ \text { born }\end{array} & \begin{array}{c}\text { No. } \\ \text { weaned }\end{array} & & \begin{array}{c}\text { No. } \\ \text { mated }\end{array} & \begin{array}{c}\text { No. giving } \\ \text { birth }\end{array} & \begin{array}{c}\text { No. } \\ \text { born }\end{array} \\ 0 & 6 & 6 & 32 & 30 & 6 & 6 & 45 \dagger \\ 3 & 5 & 5 & 38 & 29 & 4 & 4 & 18 \\ 6 & 6 & 6 & 55 & 47 & 6 & 5 & 39 \\ 9 & 6 & 6 & 51 & 45 & 6 & 5 & 43 \\ 12 & 6 & 6 & 37^{*} & 31 & 6 & 4 & 32 \\ 21 & 5 & 5 & 33 & 28 & 5 & 3 & 30\end{array}$

* As no difference was apparent between the different yeasts, the results for the three have been combined.

$\uparrow$ Plus one litter killed and eaten at birth.

\section{DISCUSSION}

Toxic effects of yeast

Yeast, when given as the major source of dietary protein, has been criticized on two counts. First, as a source of protein its value is limited by its content of sulphur amino acids. Secondly, it can cause massive hepatic necrosis, which is prevented by vitamin E or sulphur amino acids (Goyco, I956) or selenium (Kelleher, Gitler, Sunde, Johnson \& Baumann, I959).

We were not concerned with these effects as our diet contained an abundance of vitamin $\mathrm{E}$ and sulphur amino acids, nor was the yeast the major part of any of the diets used, but only a supplement to an already complete diet.

\section{Digestive disturbances}

There have been several reports of various digestive disturbances in human beings after the intake of more than $15 \mathrm{~g}$ dried yeast daily. von Loesecke (1946) summarizes ten reports that cover a diversity of opinion, ranging from a statement that $85^{-1} \mathrm{IO} \mathrm{g}$ can be consumed daily without ill-effect to another that ill-effects follow consumption of as little as $3 \mathrm{~g} /$ day. Not all these results can be taken at their face value. For example, Ruffin \& Cayer (1944) made the following observation: three out of thirtyfour subjects complained of gastro-intestinal symptoms when given placebo, six out of thirty-six complained when given liver, and nine out of thirty-nine when given yeast. The authors concluded that yeast causes gastro-intestinal symptoms. Yet in the same series of experiments they reported nausea and vomiting in eight cases out of thirty-seven fed on liver, and in only two out of thirty-eight fed on yeast.

The Memorandum of the Medical Research Council: Accessory Food Factors Committee (1945) lists four series of experiments, in three of which complaints were 
made by a small number of subjects consuming $7^{-10} \mathrm{~g}$ yeast daily. Here, again, one experiment showed twenty cases of 'digestive and other upsets' in I60 children given $7 \mathrm{~g}$ yeast/day and seven cases in 140 controls. From the evidence available it seems that, though many people can tolerate as much as $100 \mathrm{~g}$ yeast without apparent illeffect, others occasionally suffer disorders from as little as 7-10 $\mathrm{g}$, but no convincing explanation has been found. The M.R.C. Report concludes that about $15 \mathrm{~g}$ dried yeast may be regarded as the maximum permitted daily dose.

We have here made no direct contribution to this discussion, except the negative one that we were unable to detect any ill-effects on the rat, even after giving yeast at abnormally high levels.

\section{Uric acid}

The relatively high purine content of yeast has often led to the view that it may cause ill-effects due to accumulation of uric acid. von Loesecke (I946) lists six reports of increased urinary excretion of uric acid after consumption of yeast by human subjects, two reports showing no increased excretion, one report of no effect on blood levels of uric acid and one report of an increase. However, the American Medical Association: Council on Foods (1939) concluded that it does not seem probable that, at least in the quantities normally consumed, it causes an increase in production of uric acid sufficiently great to exert a harmful effect on the organism or to lead to the formation of uric acid stones'. Since then Cremer \& Beisiegel (I943) showed no significant effect on uric acid in blood or its excretion in urine in human subjects on the consumption of Io g yeast/day for a long period.

\section{S UMMAR Y}

1. One hundred and forty-four rats, including controls, received food yeast at various levels in an attempt to discover a reason for the digestive disturbances sometimes observed in human beings consuming more than $15 \mathrm{~g}$ yeast/day.

2. Candida arborea, Zygosaccharomyces lactis or Torulopsis utilis was added to an already adequate diet, at levels of $3,6,9,12$ or $21 \%$. The animals were given the diet with the different yeast supplements for $4^{-6}$ months, when half were killed, various organs being weighed and examined histologically. The remaining animals were mated and their fertility was observed.

3. No effects were observed as judged by weight gain, efficiency of food conversion, overall body and carcass lengths, blood and urine picture, histological picture of liver, spleen, thymus, kidney and adrenals, dry weight and fat content of liver, and fertility.

We thank Bovril Limited, for facilities for housing the animals, Tate and Lyle, Limited for the samples of yeast used and Mr Peter Nunn for technical assistance. We are particularly grateful to Dr A. C. Thackray, of the Bland-Sutton Institute, for his opinion on the histological sections. 


\section{REFERENCES}

American Medical Association: Council on Foods. (1939). Accepted Foods and their Nutritional Significance. Chicago: American Medical Association.

Cremer, H. D. \& Beisiegel, L. (r943). Klin. Wschr. 22, 187.

Goyco, J. A. (1956). F. Nutr. 58, 299.

Kelleher, W. J., Gitler, C., Sunde, M. L., Johnson, M. J. \& Baumann, C. A. (r959). F. Nutr. 67, 433. Medical Research Council: Accessory Food Factors Committee (1945). M.R.C. (War) Memor. no. I6. Ruffin, J. M. \& Cayer, D. (1944). F. Amer. med. Ass. 126, 823 .

Thomson, W. (1936). F. Hyg., Camb., 36, 24.

von Loesecke, H. W. (1946). F. Amer. diet. Ass. 22, 485 . 